\title{
FREE GRACE VERSUS FREE WILL: John Wesley's Understanding of Humanity and His practice of Pastoral Guidance
}

\author{
Ho Pheng Koo \\ Methodist Theological School, Sarawak, Malaysia \\ Email: peacemethodistchurch@yahoo.com
}

Submit: 14 July $2021 \quad$ Revised: 29 November $2021 \quad$ Accepted: 22 December 2021

\begin{abstract}
This article aims to discuss how John Wesley understood the debates about Free Grace and Free Will. With John Wesley's understanding, it becomes the basis for understanding humanity and its practice for pastoral guidance. The result is Wesley strived in all this evangelical pursuit to spread this "religion of love". He tirelessly and purposefully provided guidance for his people, the Methodists of the British Isles in the eighteenth century. True to this conviction, his sermons, letters and the instruction given to the life of the small groups (bands, societies, class meetings), either on the personal or communal level, Wesley continued to point them towards the goal of a sanctified life. One of the wisdom and legacy of Wesley's pastoral guidance is perhaps his innovation in finding ways and means that were suitable and appropriate in his own context to guide his flock to a mature discipleship
\end{abstract}

Keywords: free grace, free will, john wesley, humanity, pastoral

\section{INTRODUCTION}

It has been claimed that one's conception of the humanity determines the fate of every theology. ${ }^{1}$ This is true for John Wesley too. Wesley's understanding of humanity has not only affected his theological development, especially his Soteriology; it in turn impacted his practice of theology, in particular, his pastoral guidance to the thousands of "Methodists" in the British Isles almost throughout the entire eighteenth century. The latter is particularly true in the light of his concerned with practical Christianity, with the interplay of theology and the realities of daily life. ${ }^{2}$

How has Wesley understood anthropology in the light of his soteriology? How has the theology eventually play out in his practice of caring for the Methodists through his pastoral guidance? This paper seeks to response to these questions through an understanding of Wesley's soteriology and a brief survey of John Wesley's key 'productions' in the whole course of the revival movement of Methodism in the eighteenth century:

\footnotetext{
${ }^{1}$ Gunnllaugur A. Jonsson, The Image of God: Genesis 1: 26 - 28 in a Century of Old Testament Research, (Lund, Sweden: Almqvist \& Wiksell International, 1988), 1.

2 V. V. H. Green, John Wesley, (London, Great Britain: Thomas Nelson, 1964), 21.
} 
sermons, letters, and the band/societies and class meetings. ${ }^{3}$ The project also seeks to correlate Wesley's soteriology and his practice of pastoral guidance as manifested in his voluminous letters, sermons and the instructions of the band or societies or class meetings.

\section{METHODS}

The method used in this article is argumentative analysis which explains the arguments about free grace and free will in John Wesley's understanding. The presentation of these arguments is about the totally deprved imago dei and its restoration, Wesley's spiritual formation and pastoral guidance, sermons, and Wesley's letters to his acquaintances, as well as the society, the band and the class meetings.

In the final chapter on letters and the society, the band and the class meetings, I implicate John Wesley's views on free grace and free will to humility and provide practice for pastoral guidance.

\section{The Totally Depraved Imago Dei and its Restoration The Willful Rebellion of Humanity: Free will at play}

In the first "university sermon" entitled "The Image of God" which he preached in November 15, 1730, Wesley deals with issue of Christian anthropology: the original design of human nature and the tragic consequences of the Fall. ${ }^{4}$ In this sermon Wesley explained that humanity was created by God and in His image (cf. Gen. 1:26-27). Humanity is grasped only in relationship with God. As such he or she bears a Godlikeness or a relationship to God, notwithstanding his fallen nature. ${ }^{5}$ Wesley named three areas in the original creation of humanity in which the image of God was manifested. First, humanity possess ethical and unerring understanding where they are able "to distinguish truth from falsehood," "stranger to error doubt," "having just, clear and swift understanding". Secondly, humanity possessed perfect will. They are filled with the unrivaled love of God. Thirdly, humanity possessed perfect freedom. They are free to choose and their choice was to determine them

\footnotetext{
${ }^{3}$ Due to the limitation of time and space, the hymnals and the journals of the Wesleys are another rich resources for such endeavor, but are left out in this project.

${ }^{4}$ Albert C. Outler \& Richard P. Heitzenrater, ed. John Wesley's Sermon: An Anthology, (Nashville, TN: Abingdon Press, 1991), 13.

5 Ho Peng Khoo, “John Wesley and The Imago Dei”, Term Paper for John Wesley's Theology and The Imago Dei (21-951A) (Spring 2004), 2.
} 
in all things. ${ }^{6}$ In 1781, Wesley wrote another sermon "The End of Christ's Coming" where he named immortality, spirituality, understanding, affection, and the freedom of the will of humanity as natural image and termed the righteousness and true holiness as moral image. 7 He further classified human's governing power over the creation as the political image in another two sermons: "The New Birth" and "The General Deliverance."8

Wesley preached that in the perfect original condition, all the three aspects of humanity function with happiness and it is a joy to live. Humanity came forth from the hand of his Creator, then, was a free, rational, holy, righteous, steward, but not immutable. ${ }^{9}$ In his own words, God created man, not only in his natural, but likewise in his moral image. He created him not only in knowledge, but also in righteousness and true holiness. As his understanding was without blemish, perfect in its kind; so were all his affections. They were all set right and duly exercised in their proper objects, and as a free agent, he steadily chose whatever was good.

Wesley believes that it was basically the unbelief of humanity which brought forth actual $\sin .{ }^{10} \mathrm{He}$ described the fall as the willful rebellion on human's part, ${ }^{11}$ Adam, in whom all mankind were then contained, freely preferred evil to good. He chose to do his own will rather than the will of his Creator. He "was not deceived", but knowingly and deliberately rebelled against his Father and his king.

In his sermon Original Sin, based on Gen. 6:5, John Wesley postulated in the fallen state, humanity is in a totally depraved condition. The marks of this depravation (or original sin, as Wesley called it) are atheism, idolatry, pride, self-will, and love of the world. ${ }^{12}$ In other words, humanity in the fallen state is totally alienated from God. He also uses the medical term (qua Augustine and perhaps the medical science of his time) of

6 “The Image of God,” Albert C. Outler \& Richard P. Heitzenrater, eds. John Wesley’s Sermons: An Anthology, (Nashville, TN: Abingdon Press, 1991), $15 \mathrm{ff}$.

“The End of Christ's Coming”, Albert C. Outler. Ed. The Bicentennial Edition of The Works of John Wesley Edition, Vol. II, (Nashville, TN: Abingdon Press, 1985), 474 - 476. There after, eg. The Bicentennial, II: 474 $-476$.

${ }^{8}$ Cf. "The New Birth", Albert C. Outler, Ed. The Bicentennial, II: 188; "The General Deliverance", The Bicentennial II: $436-450$.

9 Irwin W. Reist. “John Wesley's View of man: A Study In Free Grace Versus Free Will” Wesleyan Theological Journal Vol.7, No.1 (Spring 1972): 27.

10 "On the Fall of Man", Albert C. Outler. Ed. The Bicentennial, II:403.

11 “On the Fall of Man”, Albert C. Outler. Ed. The Bicentennial, II:403.

12 “Original sin”, Albert C. Outler. Ed. The Bicentennial, II: 185. 
"disease" to describe this sin-sick situation. In his language, the whole human race is wounded and diseased and needs a Physician. Christ is the "great physician of souls [who] applies medicines to heal this sickness."13

\section{The Prevenient Grace of God in Christ: Free Grace at play}

The controlling factor in Wesley's theology is a soteriological, anthropological emphasis upon God's grace to all humanity as "diseased" sinners, totally depraved and totally alienated from God ("dead" is also the word used to describe the separation from God). Death become a punishment for the sin of Adam who was in some way the representative of all human being (cf. 1 Cor. 15:22). According to Wesley, "In one sense, indeed, Adam's sin was not ours. It was not our personal fault, our actual transgression. But in another sense it was ours; it was the sin of our common representative..."14 In this way, Wesley also argued that although death affected all humanity, spiritual or eternal death is inflicted only for actual sins. It is each individual's sins which bring condemnation. It is therefore clear that original sin cannot destine us to eternal destruction contrary to our own will. We died in our own sinfulness, totally unable to deliver ourselves and in need of God's grace. In the corrupted fallen state, the natural image was marred. Humanity is confused and often in error; his or her will was affected by devilish passions. The political image was also lost in part. His or her moral image was totally lost. ${ }^{15}$

This soteriological, anthropological emphasis therefore must begin with grace. For Wesley, 'grace' given by God is the very act of God himself. It is his loving personal Presence at work in our lives. ${ }^{16}$ It is the blessings or divine unmerited favor or approval. ${ }^{17}$ Wesley however also defines grace in another way: 'By the grace of God' is sometimes to be understood that free love, that unmerited mercy, by which I, a sinner, through the merits of Christ am now reconciled to God. But in this place it rather means that power of God the Holy Ghost which 'worketh in us both to will and to do of his good pleasure'. As soon as

\footnotetext{
13 “Justification by faith", Albert C. Outler, Ed. I:192, also in “Original sin”, Albert C. Outler, Ed. II:184.

14 "The Doctrine of Original Sin" cf. Thomas Jackson, The Works of John Wesley Vol. IX Letters and Essays, (Grand Rapids, Michigan: Zondervan, 1958), 418.

15 “The End of Christ's Coming”, Albert C. Outler \& Richard P. Heitzenrater, eds. John Wesley's Sermons: An Anthology, (Nashville, TN: Abingdon Press, 1991), II: 446.

16 "Fall of Man", Albert C. Outler, Ed. The Bicentennial, II:411, cf. 1 Cor. 15: 22; Rom. 5:18.

17 “Salvation by Faith,” Albert C. Outler, Ed., The Bicentennial, I: 126.
} 
ever the grace of God (in the latter sense, the power of his Spirit) takes place therein. And now we can perform, through God, what to man was impossible. 18

So understood, grace is simply the salvific power of God given to all who believe; it is the power of the Holy Spirit given to believers for obeying Christ. This grace of God through the atonement which Christ Jesus first made for salvation is the precondition to deliver human from sin's enslaving power. It is called the Prevenient grace. Prevenient grace simply refers to the grace of God that goes before or precedes any movement of man toward God. Grace flows from the Father's self-giving love for lost humanity (John 3:16-18), and is mediated through the active life and obedient death of the Son. The Holy Spirit administers the finished work of the Son through his convicting, converting, regenerating, and justifying work in the hearts of repentant sinners (John 16:8-11). ${ }^{19}$

In Wesley's theological discourse, Prevenient grace of God is common to all. It is a definite kind of grace given to all in order that humanity may be excluded from the natural state, where one is no longer exclusive of God's grace. ${ }^{20}$ In this understanding, Prevenient Grace is irresistible. Furthermore, Wesley also believed in the continual activity of God in one's life, i.e. the Prevenient grace sensitizing and inviting us to response to the salvific act of Jesus Christ. 21 This suggests that human may either choose to respond to, ignore or resist this activity. It also implies that Preveninet Grace, so understood, is resistible. This grace is freely offered by God to all humanity but in the context of Wesley's via salutis, it is not sufficient to bring humanity to the justification of God. The justification of God required a person to response to the Holy Spirit's present work in his or her life, and consequently one might display righteousness in one's life. The free will and thus the responsibility that comes with it come into play.

\footnotetext{
18 "The witness of our own Spirit", Albert C. Outler, Ed., The Bicentennial, 1:309, (also, cf. Sermon "The Good Steward", Albert C. Outler, Ed. The Bicentinnial, II: 286).

${ }^{19}$ Steve Watzki, A Preliminary Defense of Prevenient Grace, http://www.imarc.cc/pregrace/v18n2witzki.html

${ }^{20}$ Wesley used "natural state" in his sermon "Original Sin" to describe one who is exclusive of God's grace. Wesley also pointed out in his "On Working Out our Own Salvation" that there is no one who is actually left in the natural state because no one is excluded from the Prevenient grace of God.

${ }^{21}$ Randy L. Maddox. Responsible Grace: John Wesley's Practical Theology. (Nashville, TN: Kingswood Book, 1994), 90.
} 
Maddox has rightly pointed out that Wesley's practical-theological concern is for responsible Christian growth in response to God's grace. ${ }^{22}$ Although Wesley emphasized the sufficient of Christ atonement for the whole humanity, he did not agree that it is irresistibly imposed upon any person. ${ }^{23}$ Wesley was careful to reject the improper theological understanding of justification by the imputation of Christ's righteousness. ${ }^{24}$

In other words, God's grace works powerfully, but not irresistibly and it is co-operant. God empowers each human his or her "response-ability", without overriding his or her responsibility. ${ }^{25}$ But what exactly is our responsibility? Wesley's 1748 sermon on "The Great Privilege of Those who are Born of God" define this "responsibility" as a "spiritual reaction" to God's Spirit acting in one's life. Within the sphere of grace, it is a sinner's reflexive response. Wesley has work out very well in his practical theology the tension between the grace of God and the free will response of human. His concept of 'sanctification' as "growth in grace" and "going on from grace to grace" is another excellent way of demonstrating the constant need of human response to the grace of God. Without the response on human part, the grace as God's activity in our lives remains the gift yet to be claimed. This understanding is well play out in pastoral guidance he offered in his ministry and the spiritual formative programs he has implemented for the spiritual life of the Methodists, which will be discussed in the latter part of this paper.

While Wesley affirmed the grace of God at work in the lives of all, he too believed in the free will response from each individual. He knew that since freewill is given to all, along the via salutis there is the possibility of regression. One could choose to response to receive or reject the justifying grace of God (the work that God has done "for us") to begin this salvific journey. Along the journey, from time to time, one could still choose not to love God or neighbors (or sanctification, the work that God has done "in us"). Maddox has pointed out that in this respect, Wesley was contrary to the reformed scholastics "who argue that a person's justification is instantaneously complete and irreversible, it cannot be endangered

\footnotetext{
22 Randy Maddox, Responsible Grace: John Wesley's Practical Theology, 104.

23 Randy Maddox, Responsible Grace: John Wesley's Practical Theology, 105.

24 "The General Spread of the Gospel," Albert C. Outler, Ed., The Bicentennial, II: 489.

25 Randy L. Maddox, Responsible Grace: John Wesley's Practical Theology, 55, 86.
} 
by lack of subsequent growth in holiness." 26 Thus Wesley saw the need for intentional and purposeful pastoral guidance in order that one may continue to walk along the via salutis.

Of course Wesley's soteriological telos was none other than the restoration of the Imago Dei. In his sermon "On Predestination", Wesley used three key words which he continued to pursue to theologize his understanding of the restoration of the Imago Dei: "justified", "sanctified" and "glorified". Later, Wesley equated the restoration of the Imago Dei to sanctification, in which one shall be saved from all inward and outward sin into all inward and outward holiness. ${ }^{27}$ In other words, for Wesley, sanctification brings about a real and gradual 'therapeutic' moral transformation. While faith is the mark of justification, love is the mark of sanctification. Love is the supreme goal toward which the life of faith is directed. ${ }^{28}$ In Wesley's understanding, one will experience 'entire sanctification', a perfection of love moment by moment. ${ }^{29}$ It is promised to every Christian and the power of Holy Spirit could take totally fallen human beings and over time completely restore in them the image of God, such that they would fully love God and their neighbor as God has loved them in Christ. ${ }^{30}$ However, Wesley also argued that people who had experienced entire sanctification sometimes fell from that state, and some of these subsequently recovered it. ${ }^{31}$ Entire sanctification does not assured immunization from $\sin .^{32}$

In the light of such theological discourse, Wesley was made aware of the possibility of backsliding along the path of salvation toward a life of loving God and neighbor. He intentionally and purposeful provide pastoral guidance to the life of all the Methodists to reduce that possibility. Wesley continues to guide his fellow "Methodists" by holding firm to the tension between resisting "the work of man" as means to salvation and the responsiveness of all to the grace of God. In his sermons and letters and instructions given

${ }^{26}$ Randy L. Maddox, Responsible Grace: John Wesley's Practical Theology, 158.

27 "On Predestination", Albert C. Outler, Ed., The Bicentennial, II: 416.

28 Theodore Runyon, The New Creation: John Wesley's Theology Today, (Nashville, TN: Abingdon, 1998), 86. Also cf. John Wesley, "The Law Established through Faith, II", Albert C. Outler, Ed. The Bicentennial, II: 38.

${ }_{29}$ John B. Cobb, Grace \& Responsibility: A Wesleyan Theology for Today, (Nashville, TN: Abingdon, 1995), 106, and John Wesley, “A Plain Account of Christian Perfection”, Thomas Jackson, Ed. The Works of John Wesley Vol. 11, (Grand Rapids, Michigan: Zondervan, 1958), p. 420ff; John Wesley, "Brief Thoughts on Christian Perfection", Thomas Jackson, Ibid., 11: 446f.

${ }^{30}$ Henry H. Knight III, “Consider Wesley”, Joel B. Green, Ed., Catalyst: Contemporary Evangelical Perspectives For United Methodist Seminarians, Vol.30, No.4, (April 2004), 7.

31 John Wesley, "A Plain Account of Christian Perfection...", 11: 426 - 427.

32 John Wesley, "Christian Perfection”, Albert C. Outler, Ed., The Bicentennial, II: $104-105$. 
to the bands, societies or class meetings, he never fails to promote such guidance toward Christian Perfection. The will be discussed in the following chapters.

\section{Wesley's spiritual formation and pastoral guidance}

Steve Harper in his works has demonstrated how spiritual formation concerns were central in the life of John Wesley and in early Methodism. ${ }^{33}$ Although this is not the focus of this project, Wesley's spiritual formation must have impacted the way he provided pastoral guidance to the whole Methodist Movement. A survey of all his works will inform us how his past familial experience has shaped him in his pattern of pastoral guidance. For example, Wesley's upbringing and the mentorship he had received from his mother has contributed to his later practice of guidance. In a letter to his mother, he said, "If you can spare me only that little part of Thursday evening which you formerly bestowed upon me in another manner, I doubt not but that it would be as useful now for correcting my heart as it was then for forming my judgment." 34 It is this kind of upbringing which instilled a spirituality in John Wesley which served as a formative example as he provide guidance. Although Wesley emphasized the use of the means of grace to promote spiritual growth, the spiritual heritage of his family has also provided him a realistic look at the different struggles of spiritual life without simply spiritualizing everything. There are many resources where Wesley used as "means" of providing pastoral guidance, such as hymnals, pamphlets, journals, sermons, letters etc. In this paper, I have chosen three of Wesley's approaches to provide pastoral guidance: the sermons, the letters, and the life in the small groups (i.e. bands, societies, and class meetings).

\section{The sermons}

The Sermons represent a part of Wesley's written understanding of God's redemptive work. ${ }^{35}$ Wesleyans to this present day still believe that holiness of heart and life is essential to the Christian sojourn. Love perfected in the individual, mirrored after the example of Jesus, will always be a mainstay of a Wesleyan understanding. Wesley stated in

\footnotetext{
33 Steven Harper, “John Wesley: Spiritual Guide” Wesleyan Theological Journal, Vol.20, No.2 (Fall 1985): 91. Also cf. Steven Harper's work Devotional Life in the Wesleyan Tradition (Nashville: The Upper Room, 1983).

${ }^{34}$ Frank Baker, Ed., The Works of John Wesley, (Letters: I), vol. 25, (Oxford: Clarendon Press, 1980$), 329$.

35 Ryan N. Danker, An Introduction (Thomas Jackson, editor) The Sermons of John Wesley1872 edition, http://wesley.nnu.edu/john_wesley/sermons/intro.html.
} 
his own preface to the Sermons, "I have accordingly set down in the following sermons what I find in the Bible concerning the way to heaven; with a view to distinguish this way of God from all those which are the inventions of men."36 Wesley's aim was to preach the biblical gospel so as to lead people to live a life of Perfection that is at par with the Bible. In his General Rules of the United Societies, Wesley spelled out the fact that when the desire of salvation is "really fixed in the soul, it will be shown by its fruits." ${ }^{37}$ As mentioned earlier in this paper, this is the love-perfected, sanctified life which Wesley believed to be taught in the Bible, a life bringing forth the fruits worthy of God. Elsewhere, in his discussion of ministerial functions, he said, "In order to build up the flock of Christ in faith and love, I am under a necessity of uniting them together, and of dividing them into little companies, than they may provoke one another to love and good works." 38 It is therefore not surprising that the Sermons which Wesley has preached were expected to move in this direction as to help the Methodists to live lives worthy of what he called "scriptural Christianity". Outler has rightly commended: "His [Wesley] sermons are bound to be misread unless they are understood as experimental statements and restatements of his vision of the Christian life."39

A survey of the titles and content of his more than 150 sermons, about two-third of them could be categorized as doctrinal/salvation. ${ }^{40}$ This is one of Wesley's key ways of guiding the Methodists to experiencing the scriptural doctrine of salvation. Wesley believed that preaching the sermons and eventually through the work of the Holy Spirit will open the "spiritual senses" of a person so that he or she may begin to feel the workings of the Spirit of God in his heart; to taste and to see how gracious the Lord is; to hear the word that proceeds out of [God's] mouth, allowing them to take charge of his thoughts, words, and actions; and to discern the spiritual good and evil. Wesley summed out all these figurative

36 “The Law Established through Faith, II", cf. Albert C. Outler. ed. The Bicentennial, I: 106.

37 John Wesley, “The Nature, Design, And General Rules of the United Societies," Thomas Jackson, Ed. The Works of John Wesley, Vol. III Address, Essays, Letters (Grand Rapids, Michigan: Zondervan Publishing House, 1872), 270

38 John Wesley, "Prophets and Priests," in Albert C. Outler \& Richard P. Heitzenrater, Ed., John Wesley's Sermons: An Anthology, (Nashville, TN: 1991), 545.

39 Albert C. Outler, John Wesley's Sermons: An Introduction, (Nashville, TN: Abingdon press, 1991), p.104

40 cf. Appendix 2 Categorizing Wesley's sermons based on Albert C. Outler ed. The Works of John Wesley Vol. 1 - 4 , Nashville, TN: Abingdon Press, 1985. 
expressions with the expression "faith". ${ }^{41}$ This is the primary way of providing guidance to help a person to be changed from spiritual death to spiritual life. Preaching becomes a means of pastoral guidance to initiates the potential of faith, which in turn makes up the defects of the "spiritual senses".

Another significant theme of the sermons is that which I called "Christian Living". Out of the more than 150 sermons, about 37 of them could possibly be classified under such category. As I have argued that Wesley's telos of spreading the scriptural holiness was eventually to see people turning to God and be transformed to an entirely sanctified life to love God and neighbor. Wesley's ways of working toward this goal is via what he termed the means of grace, which included two broad categories: "work of piety" and "work of mercy". In defining these two separate categories, Wesley postulated that religious actions are commonly termed works of piety (e.g. prayer and fasting, searching the scriptures by reading, hearing and meditating upon it; receiving the Holy Communion); and works of charity or mercy are goods works such as almsgiving. Wesley firmly believed that these are ordinary channels whereby [God] might convey to men preventing, justifying, or sanctifying grace. ${ }^{42}$

Wesley strongly emphasized that these are "means ordained of God as usual channels of his grace" and warned that these means could be easily be mistaken as the end if love of God is not the motive and the end. ${ }^{43}$ In his own words, "[...] some [...] mistake the means for the end, and to place religion rather in doing those outward works than in a hear renewed after the image of God." 44 Thus in providing pastoral guidance to live a sanctified life, Wesley's emphasized the important of "pure and holy intention" as the central theme to the telos. Wesley clearly explained in "Upon our Lord's Sermon on the Mount Discourse the Sixth: Matthew 6:1-15" that either works of mercy or piety (in this case, almsgiving or prayer), the ultimate end of these good works is "that they may glorify our Father which is in heaven." ${ }^{5}$ He further contended "opus operatum, the mere work done, profiteth nothing;

${ }^{41}$ John Wesley, “On Living without God”, Albert C. Outler \& Richard P. Heitzenrater. John Wesley's Sermon: An Anthology, op. cit., p. 570.

${ }^{42}$ John Wesley, "The Means of Grace", Albert C. Outler. ed. The Bicentennial, I: $381 \mathrm{ff}$.

43 John Wesley, "The Means of Grace", Albert C. Outler. ed. The Bicentennial, I: 378 \& 381.

${ }^{44}$ John Wesley, "The Means of Grace", Albert C. Outler. ed. The Bicentennial, I: 378.

45 John Wesley, "Upon our Lord's Sermon on the Mount Discourse the Sixth: Matthew 6: 1 - 15", Albert C. Outler, Ed., The Bicentennial, I:577ff. 
that there is no power to save but in the Spirit of God, no merit but in the blood of Christ; that consequently even what God ordains conveys no grace to the soul if you trust not in him alone." Wesley's emphasis is still "to use all means as means; as ordained, not for their own sake, but in order to the renewal of your soul in righteousness and true holiness." 46

While guiding the Methodists through the means of grace, Wesley noticed their "psychological needs". Wesley did not spiritualize the body and the emotions. Although Wesley did not directly use the term 'psychological needs', he did make room for the possibilities of problems facing the emotions of each individual. In explaining about the perfection of Christians, he did not exclude the possibility of "a thousand other infirmities." 47

Several sermons from the 37 mentioned earlier will be helpful to illustrate how Wesley has provided pastoral guidance for those who were having psychological needs. One of these sermons is "Wandering Thoughts". Like the many in the eighteenth century who employed the scientific quest for knowledge, his first define wandering thoughts. Wesley lists the possible sources of wandering thought. Wesley pointed out that multitudes of outward impulses could give rise to our wandering thoughts. Wesley recognized that there are wandering thoughts that come from a diseased body: nervous disorder. He was prepared to point out the possibility of evil spirits at work, which many contemporary Christians were less likely to accept as a possible reason. ${ }^{48}$ He went on to describe how this "wandering thought" could possibly affect our relationship to God in the light of the goal of a sanctified life. Those which possibly affected this relationship were termed sinful. For example, thoughts which spring from a revengeful temper, from pride, or lust, or vanity which leave God no room in our minds are called sinful. Wesley explained that wandering thoughts coming from "infirm constitution or from some accidental weaknesses or distemper they are as innocent as it is to have a weak constitution or a distempered body." 49 Wesley's next important quest about the issue was to find solutions. To Wesley, one could pray for deliverance from those thoughts which jeopardize one's relationship to God. But with regard to the latter sort of wandering thoughts coming from corruptible body,

\footnotetext{
46 John Wesley, “The Means of Grace”, Albert C. Outler. ed. The Bicentennial Edition, II: 396 - 397.

47 John Wesley, “On Perfection”, Albert C. Outler. Ed. The Bicentennial Edition, III: 73.

48 John Wesley, "Wandering Thoughts", Albert C. Outler, Ed. The Bicentennial Edition, II:129.

49 John Wesley, "Wandering Thoughts", Albert C. Outler, Ed. The Bicentennial Edition, II:133.
} 
others and evil spirits, Wesley guided all who read or listened to his sermon to pray not for entire deliverance (which he argued was only possible when a person died!) but that as one suffer with the reality of these infirmities, we may be conquerors and to increase our love for God and man.

In another sermon "Heaviness through manifold temptations", Wesley was aware of "religious depression" with its psychological implications. His sermon was designed to provide pastoral guidance "to help believers avoid any further slide from depression into 'darkness' or sinful despair. ${ }^{50}$ Again we found Wesley began his discourse by defining the term 'heaviness'. ${ }^{51}$ A person who experiences such heaviness is still in relationship with God and does not loss his or her faith, hope, joy and the power to over sin. He defined heaviness the continue-for-some-time emotion of "grief" which sinks deeply into the soul. It overshadows and presses upon one's whole being and thus weakens it. Like the faithful scientific mind of the enlightment, Wesley then went on to dig the "roots" of this heaviness. Wesley again pointed out the "manifold" possibilities such as sickness and pain of body, good and evil spirits, long term illness, calamities, physical exhaustion, bereavement, and the attack from the evil ones. In line with his Scriptural understanding, Wesley also include the possibilities of God's sovereign will for one to be in such heaviness when one sinned against God or when one is well aware of his or her own spiritual condition. One of Wesley's ways of providing pastoral guidance is to relate the issue in the light of its relationship to God. What has heaviness to do with one's relationship with God? Wesley listed the increase of faith, hope and love for God, and the holiness of life which brings glory to God. ${ }^{52}$

In his short conclusion, Wesley again provided a short and precise solution to the issue. He guides his hearers by urging them to watch and pray and strife not to fall into the darkness of unfaith. One needs not avoid heaviness of heart but to behave as guided and waited for the Lord to bring one into another season of life.

50 "An Introductory comment for 'The Wilderness State' and 'Heaviness through manifold temptations", Albert C. Outler, Ed., The Bicentennial Edition, II: 202 - 204.

51 John Wesley, "Heaviness through Manifold Temptations", Albert C. Outler, Ed. The Bicentennial Edition, II: 222, 225

52 John Wesley, "Heaviness through Manifold Temptations", Albert C. Outler, Ed. The Bicentennial Edition, II: 234. 
Another good example of how Wesley provided pastoral guidance is seen in his "The Cure of Evil-speaking". The purpose of this sermon is geared toward holiness of heart where one could love his or her neighbor by not speaking evil of an absent person (or "talebearing" or "backbiting" in Wesley's terms) ${ }^{53}$. In so doing, one truly glorifies God. One would again suspect a pattern in the analysis of the last two sermons to appear in this work. Wesley began his sermon by giving the definition of the 'evil-speaking'. Wesley went at length to spell out the details of the situations in evil-speaking and warn of how evil-speaking "gratifies our pride to relate those fault of others whereof we think ourselves not to be guilty" and it comes with a lot of negative unkind tempers. ${ }^{54}$ Following Wesley's pattern of pastoral guidance, the question of the sources and causes of such problem will naturally follow. Indeed, he pointed out that this comes from the sin of hatred, in order that one may "punish the wicked". Wesley expounded Matthew18: 15 - 17 to provide solution to such a problem in Christian living. Following the Matthew text, Wesley pointed out the first rule is to speak individually with the person whom one has found committing sin. He was sensitive to the fact that such approach requires not only boldness to speak truth but to be done in love and humility. A messenger or writing a note to the person could be used only when it is absolutely necessary. It is interesting to see how Wesley often thinks of the most practical way of reaching the goal of perfecting our love for God in our Christian living. He knew in the practical situation, there will be exception when speaking about others without his or her presence is necessary in the event when his or her plan to endanger others' property or life is known. Yet this is "only so much as is necessary for the end proposed." 55 When this is not workable, according to this biblical passage, one need to take one or two who truly care and are able to deal with the situation with love and humility. The last resort was to inform the "church", which Wesley taught of the leaders in the societies. Wesley did not miss another link of his pattern, viz. to talk about how this issue is related to a life of holiness. In his conclusion, he comes back to this issue and pointed out that love of God should be evident in this issue as love of neighbor. Nothing is more important than this telos.

\footnotetext{
53 John Wesley, "The Cure of Evil-speaking": 252 - 253.

54 John Wesley, "The Cure of Evil-speaking": 253.

55 John Wesley, "The Cure of Evil-speaking": 257 - 258.
} 
Although the examples cited are not exhaustive, one began to observe a certain pattern of Wesley's pastoral guidance. Wesley explored those issues of Christian living very much the way his contemporary empiricists and scientists would have done in their methodology. Wesley attempted to begin with an "issue" of Christian living with his own "diagnosis", which included a detail definition of the issue. As far as he could, he tried to think of the manifold possibilities of the causes and sources of the problem. Like a scientist, his probe deep into the possible variables. At times, he went to the extent of listing the exceptions. Together with the plain language of his sermon, his pastoral guidance become clear and straight forward. He offered clear directions as to how a Christian could follow in order to live a life of holiness. The relationship with God to love God and live before him a life of holiness - entire sanctification or perfection of love continue to guide Wesley in his way of providing pastoral guidance.

\section{The Society, The Band and The Class meetings}

\section{The Society}

Whitefield commented Wesley's genius in forming the class meeting. Wesley holds firmly to the conviction that each person is given the free grace and the free will to respond to God's salvation. But if one chooses to receive the grace of salvation, one is still having the potential to regress along the path of Christian perfection. He believed the necessity of guiding each individual to grow toward Christian perfection. Collins also echoed this fact: "[...] Wesley, being the astute pastoral counselor that he was, realized that individuals, left to their own devices would hardly progress in grace." 56 In fact in 1739 when Wesley was approached by several persons who asked him for additional instruction, which lead to the formation of the society meeting. 57 In his 1789 sermon "Prophets and Priests", Wesley clearly spoke of his strategy for pastoral guidance through "little companies" for the purpose of "provoking one another to love and good works." This is the telos of a sanctified life.

Of course, one could argue that such class meeting was nothing new. In fact Wesley's father, Rev. Samuel Wesley, has organized and led religious society at Epworth well before

\footnotetext{
${ }^{56}$ Collins, Kenneth. The Scripture Way of Salvation: The Heart of John Wesley's Theology. (Nashville, TN: Abingdon Press, 1997), p. 61.

57 The Works of John Wesley, Vol. 8, A Plain Account of the People Called Methodists, p. 250.
} 
the formation of London society. ${ }^{58}$ Wesley indeed drew upon the earlier Anglican "religious societies" in several ways, such as written rules and content for the society, frequency of meeting and membership, strict discipline for attendance, and the caring for the poor. ${ }^{59}$ Hardt argued that Wesley also drew upon his own personal experience of the "Holy Club" at Oxford University in establishing the Methodist societies such as regular prayer, Scripture study and discussion, and fasting. Through such meeting, Wesley was able to more effective fostered and guide the Methodists to grow in their spiritual life. It is a means of grace. Pastoral guidance in this way is not only a personal one-to-one relationship; it also fostered through mutual care and concern in the group meetings of society. Mutual care thus became another pastoral guidance that aid the members in the class meetings to be motivated to live a life of love and holiness.

\section{The Band}

In August 1738, Wesley went to Hernhut to visit the Moravian community. He was very impressed by the band meetings. He wrote in his Journal, "I greatly approve of your conferences and bands, of your method of instructing children, and in general of your great care of the souls committed to your charge."60 Wesley always has his own innovative way of using the information he has collected. He set up weekly band meetings in London and Bristol where members come for spiritual examinations. The leaders of the bands were spiritually more advanced than the others and they met weekly to discuss their members' progress. ${ }^{61}$ In the Rules of the Band Societies that John Wesley has laid out, the members were asked "What known sin have you committed since our last meeting? What temptations have you met with? How were you delivered? What have you thought, said, or

${ }^{58}$ David L. Watson. Early Methodist Class Meeting: Its Origins and Significance. Nashville: Discipleship Resources, 1985. p. 72.

${ }_{59}$ Dr. Anthony Horneck, A German, who had been educated at Oxford University and ordained to the Anglican priesthood, had begun these small parish-based societies in 1678. cf. Philip F. Hardt, The Soul of Methodism: The Class Meeting in Early New York City Methodism. Lanham, Maryland: University Press of America, 2000, pp. 9 and 153.

${ }^{60}$ John Wesley, Journal Vol. 2, p. 496.

${ }^{61}$ Philip F. Hardt, The Soul of Methodism: The Class Meeting in Early New York City Methodism. Lanham, Maryland: University Press of America, 2000, 13. 
done, of which you doubt whether it be a sin or not? Have you nothing you desire to keep secret?"62

Wesley was skillful to use organization structure to guide how the band members live their lives in the real world. This meeting becomes, for Wesley and his coworkers, the means for Christian discipleship. Although Wesley put in much effort to promote attendance, the band meetings remain poorly attended and soon after the death of Wesley, it ceased to be a motivating vision for the Methodists. ${ }^{63}$ Nevertheless, the band meetings continue to be Wesley's ideal of providing pastoral guidance. "Wesley's ideal of a band society functioning as the heart of a Methodist society, providing guidance by examination and precept, stimulating the brethren to the whole heart pursuit of godliness [...]"64

\section{The Class meetings}

Unlike the society and band meetings which drew upon Anglican and Moravian resources, the class meeting developed entirely from events which occurred within the Methodist society in Bristol. Hardt argued that the class meeting were Wesley's original contribution in response to local events rather than a 'copy' of Gaston de Renty's class meetings among the Catholics. ${ }^{65}$ A brief review of the original formation of class meeting will echo this argument.

In 1742 Wesley and several members were having a meeting to discuss ways of clearing the debt incurred in building the Bristol preaching house. One of the members suggested to divide the society into groups of twelve among those who lived near each other and to designate a leader to collect a weekly contributions of a penny each for the

62 John Wesley, "Rules of the Band Socieities Dreawn up Decmeber, 1738," in Thomas Jackson, Ed. The Works of John Wesley, vol. 8, op. cit., pp. 272 - 273. cf. David Francis Holsclaw, The Demise of Disciplined Christian Fellowship: The Methodist Class Meeting in Nineteenth-Century America, (Ann Arbor, MI: University Microfilm International, 1979), pp. 289 - 297.

${ }^{63}$ Philip F. Hardt, The Soul of Methodism: The Class Meeting in Early New York City Methodism, 13. (cf. Hardt also cited Dean, William's dissertation on this matter.)

${ }_{64}^{64}$ Philip F. Hardt, The Soul of Methodism: The Class Meeting in Early New York City Methodism, 15.

${ }^{65}$ Philip F. Hardt, The Soul of Methodism: The Class Meeting in Early New York City Methodism, 157. Hardt highlighted Henry Bett's work “A French Marquis and the Class Meeting," Wesley Historical Proceedings 18 (1992), 44 - 47, where Bett argued that de Renty had influenced Wesley by his simplicity, detachment from materials possessions and worldly pleasure, communion with God in prayer, and outreach to the poor (Wesley mentioned de Renty several times in his journal). Bett also noted that de Renty's religious-societies were more closely parallel to the society-classes of Methodism than the Anglican and Moravian style. 
paying of the debt. ${ }^{66}$ What started off with a financial function quickly began to fulfill a pastoral function. Wesley was alerted by the various difficulties which the members of the different classes encountered through such a small group contact and he seized the opportunity to turn this into a ministry of providing pastoral guidance through offering them counsel and encouragement. A stone kills two birds! Wesley believed this arrangement would greatly strengthen the pastoral oversight and in his A Plain Account of the People called Methodist he said, "I called them together all the Leaders of the classes (so we used to term them and their companies), and desired, that each would make a particular inquiry into the behavior of those whom he saw weekly."67

The class meetings were much less intense as compare to the band meetings, being a mixture of informality and firmness. ${ }^{68}$ A typical meeting usually includes opening prayer and hymn. This will be followed by class leader self-disclosure of his or her spiritual condition before requesting the individuals in the group to participate in such accountability. There will be a time of encouragement, exhortation and correction with appropriate hymn singing. ${ }^{69}$ This pattern of willfully sharing personal religious experiences and providing pastoral guidance was indeed a realization of Wesley's telos for discipleship - a sanctified life where salvation is not just rational or sentimental; it should be put into practice in the mundane of life so that transformation becomes a reality. Wesley was also well aware of the weaknesses of these awakened Methodists to go back their own ways of life. He and other lay preachers worked out quarterly examinations for the classes in the circuit on their attendance and behavior. The leaders usually record attendance and evaluated and recorded the spiritual state of the members. In addition to this measure, a system of discipline was included where those whose discipleship was unsatisfactory did not receive class tickets to attend the weekly society and class meetings for the next quarter. Wesley even excluded some members. This again illustrates clearly how Wesley

${ }^{66}$ John Wesley, "A Plain Account of the People Called Methodists", in Thomas Jackson, Ed., The Works of John Wesley, vol. 8, 252. [ also cf. David Lowes Watson, Class Leaders: Recovering a Tradition. (Nashville, TN: Discipleship Resources, 1991.) , 25 - 26.]

${ }^{67}$ John Wesley, "A Plain Account of the People Called Methodists", 252.

${ }^{68}$ David Watson, "Methodist Spirituality," in Frank C. Senn, Ed., Protestant Spiritual Traditions (New York: Paulist Press, 1986), 212.

${ }^{69}$ David L. Watson. Early Methodist Class Meeting: Its Origins and Significance. (Nashville, TN: Discipleship Resources, 1985), 115. 
has attempted to even enforce certain strict discipline as a means to guide the Methodists toward the telos of his soteriology.

\section{The letters ${ }^{70}$}

One of John Wesley's unique and very productive literary works was the thousands of letters he has written which dated most part of the eighteenth century. John Telford commended "the letters are an invaluable introduction and supplement to Wesley's Journal. They are less known and bring us into close touch with the men and women who labored with Wesley in all parts of the Kingdom and in America. They formed the most intimate portrait of Wesley we possess." 71

A study through Wesley's postal ministry will certainly amazed us for the way he provided pastoral guidance through his correspondence in what Leslie Stephen commended as "straight to the mark, without one superfluous flourish, ... as a man confined with the narrowest limits of time and space...". ${ }^{72}$ The letters also reflected what Outler has commented about Wesley: "...Wesley was more interested in speaking to the needs of any given moment than in formulating a generalized view that might cover a multitude of conceivable instances." 73 His correspondence covered almost any subjects under the sun. Frederick C. Gill in his edition of the selected letters of John Wesley said: "Wesley's interests were universal and as his letters showed, were sustained by an untiring faith, by a keen and lively intelligence and by a practical benevolence and humanity."74 Telford record shows that from the earliest letters in the collection begin in 1721 and the highest totals reach 138 in 1788 and 144 in 1789, as Methodism progressed.

I am aware that there are different ways of reading and analyzing the letters. Samuel J. Rogal suggested a three-fold categories of reading the letters: (1) the 'business' letters, constituting the majority and emphasizing the practical side of John Wesley; (2)

${ }^{70}$ I will be utilizing a paper entitled "An Asian Reflection of John Wesley's Postal Ministry in The Light of His understanding of New Creation", a paper which I have written based on John Telford's edition of "The Letters of The Rev. John Wesley". This paper was presented for the theological discussion for the First Wesleyan Seminar organized by the World Federation of Chinese Methodist Churches, 2001.

71 John Wesley. The Letters of The Rev. John Wesley, A.M. Vol. 1, John Telford, ed. (London: The Epworth Press, 1931), p. xviii. (Hereafter, John Wesley. The Letters, 1: xviii).

72 John Wesley. The Letters of The Rev. John Wesley, xv.

73 Albert C. Outler, John Wesley's Sermon: An Introduction, 69.

${ }^{74}$ Frederick C. Gill. Ed. Selected Letters of John Wesley. (New York: Philosophical Library, 1956), viii. 
Letters to various women, demonstrating Wesley's concern for and problems with the women in his life; (3) the "controversial" letters, thoroughly developed arguments permitting observation of Wesley's methods for solving highly volatile issues, most of them challenges to British Methodism. ${ }^{75}$ Wesley D. Tracy read the letters through the lens of spiritual guidance. He proposed that the letters of John Wesley were his spiritual guidance to the Methodists. ${ }^{76}$ From the selected themes categorized from the indices of his 2760 letters edited by John Telford, I proposed a six possible general themes would suffice the postulation of pastoral guidance as stated above, though not exhaustive. ${ }^{77}$ These themes included Doctrinal and Biblical Issues; Christian Living; Education, Science and Wisdom from the Past; Methodism, Societies and Mission; Church, Ecumenical; Others. This is a way of reading the letters through the lens that letters as a manifestation of the "religion of the heart" which Wesley has so dearly and firmly proclaimed through his lifelong ministry. ${ }^{78}$

\section{Doctrinal and Biblical Issues}

The doctrinal and biblical issues consisted one of the major portions of Wesley's correspondence. ${ }^{79}$ A glance at the varieties of the topics confirms Wesley's letters covered almost all the fundamental topics in systematic theology, though they were never in neatly packaged formulas. With the strong conviction of providing pastoral guidance for the Methodists to live as truly Scriptural Christians, practicing the religion of the heart and attaining the role of Christian perfection, Wesley insisted of writing these issues in plain language as he has done for his sermons. He strongly felt that the scholastically way of dealing with the subject would obscure truth more than they revealed it.

75 Samuel J. Rogal, “The Elder Unto The Well-Beloved”: The Letters of John Wesley, Journal of Religious Studies, Vol.7, No.2 (Fall 1979): 76.

76 Wesley d. Tracy, “John Wesley, Spiritual Director: Spiritual Guidance In Wesley's Letters, Wesleyan Theological Journal Vol.23, No.1 \& 2 (Spring Fall 1988): 148 - 162.

77 Ho Peng Khoo, “An Asian Reflection of John Wesley’s Postal Ministry in The Light of His Understanding of New Creation”, First Wesleyan Seminar, WFCMC. (Taiwan, Taipei: World Federation of Chinese Methodist Churches, 2001), $13-22$.

${ }^{78} \mathrm{I}$ am also aware that the letters could be read as historical documents tracing the development of the British Methodism. In fact Telford divided the Letters into eight historical periods: Nov. 3, 1721 to Nov. 14, 1741 ; May 17, 1742 to Nov. 27, 1750; Feb.4, 1751 to Jan. 10, 1758; Jan. 16, 1758 to Feb. 28, 1766; Feb. 28,1766 to Dec. 31, 1773; Jan. 8, 1774 to Dec. 31, 1782; Jan. 2, 1783 to Dec. 27, 1787 and Jan. 8, 1788 to Feb. 24, 1791. The letter during these periods provides a lot of insights for the understanding of the movement's history.

${ }^{79} \mathrm{Cf}$. Appendix of the themes which I have categorized based on Telford indices of selected theme. 
Elsewhere Wesley also insisted a plain meaning of the Scripture for all the lay people. Without which, Wesley believed there was no way of guiding them to attain the religion of the heart, which is the scriptural faith of loving God and neighbor. In his own words,

I design plain truth for plain people: Therefore, of set purposes, I abstain from all nice and philosophical speculations; form all perplexed and intricate reasonings, and as far as possible, from even the show of learning, unless in sometimes citing the original Scriptures. I labour to avoid all words which are not used in the common life; and, in particular, those finds of technical terms that so frequently occur in which to common people are an unknown tongue. ${ }^{80}$ Under the theme of Doctrinal and Biblical Issues, Wesley was particularly concern in guiding the members to attain perfection in their via salutis. ${ }^{81}$

\section{Christian Living}

The theme of Christian Living broadly covered three major aspects: physical, spiritual and moral (cf. Appendix "Christian Living" \& "Medicine"). Wesley emphasized the need for all Christians to live according to the scripture. He affirmed in his journal that the word of God is the way to heaven and formed his guide for the moral, scriptural and physical well being of Christian living..

Wesley realized the need to be spiritual director in his postal ministry to guide the spiritual formation of his members. He was well aware of their struggles and he discussed with them, directed them from the outward behaviour to the deepest emotion of a person. He dealt with the topics of dress, busybodies, Christian prudence, ecstasies, emotion, fear, suffering, taxes, value of time, vanity, to name a few. Wesley directed them with the rule: "Keep close to your rule, the Word of God, and to your guide, the Spirit of God; and never be afraid of expecting too much." 82 His concern for a sanctified-perfected life knows no limit in the mundane of life. As a spiritual director, Wesley provides very open, straightforward and directive guidance. Christian perfection (or Entire Sanctification) was the central theme in Wesley's preaching and teaching, the letters are saturated with this theme.

\footnotetext{
80 John Wesley, The Works of John Wesley Vol.V., (Grand Rapids, Michigan: Zondervan Publishing
} House), 2.

81 Wesley Center Online. http://wesley.nnu.edu/john_wesley/letters/1774.htm.

82 Frank Baker, “John Wesley, Postal Pastor”, James S. Udy \& Eric G. Clancy, Dig or Die: Papers given at Wesley Heritage Conference. Sydney 1980, (Australia: World Methodist Historical Society, Australian Section, 1981), 37. 
Wesley often encourages two forms of spiritual guidance to Christian perfection: director-directee and mutual guidance. ${ }^{83}$ In a letter for Frances Godrey, Wesley wrote, "It is a blessed thing to have fellow travelers to the New Jerusalem. If you cannot find any you must make them; for none can travel that road alone." 84 Wesley D. Tracy demonstrated in her work that John Wesley's spiritual guidance found in the Letters were marked with affection, reciprocal openness, encouragement and accountability. Having intervene in her life, Wesley took a personal interest in the life of Bolton and over a period of 29 years he wrote her some 130 letters of spiritual guidance - sanctification, suffering, service, to name a few. ${ }^{85}$

Despite Wesley's unfulfilled marriage, he continued to provide guidance to many regarding such issue. Wesley did not lock himself in that dilemma. Instead, for the sake of the Gospel, he reached out to them, to guide even more for the happiness of their marriages. 86

\section{Education, Science, Wisdom From The Past}

Wesley was enthusiastic to provide education to the young people of his time. His enthusiasm was frequently shows up in his letters. Through his letter writings, he was able to discuss and guided the formation of Kingswood School with his coworkers such as James Hutton, Ebenezer Blackwell and George Whitefield. ${ }^{87}$

He was keen in pursuing knowledge of all kinds. His taste for scientific knowledge was something that is unusual. In his pastoral letters, his subjects on science ranges from astronomy, building, earth, moon to candle making, electricity and even Isaac Newton and Psythagoras! ${ }^{88}$

One could not cease to admire Wesley's knowledge of the church fathers. It was at his fingertips when he dealt with the controversies. He was able to quote Jonathan Edward's A Faithful Narrative of the Conversion of many hundred souls in Northamption to

${ }^{83}$ Wesley D. Tracy, “John Wesley, Spiritual Director: Spiritual Guidance In Wesley’s Letters”. Wesleyan Theological Journal, Vol.23 No.1 \& 2 (Spring Fall 1988): 149.

84 John Wesley, The Letters, 8: 158, Aug. 2, 1789.

${ }^{85}$ Wesley D. Tracy, “John Wesley, Spiritual Director: Spiritual Guidance In Wesley’s Letters”, 153.

${ }^{86}$ Wesley D. Tracy, “John Wesley, Spiritual Director: Spiritual Guidance In Wesley’s Letters” 43.

87 John Wesley, The Letters, 1: 292f, 302, 305, 313 etc.

88 cf. Appendix on "Science" for the catagorized selected themes based on the themes of the Letters. 
account for the ecstatic conditions of revival where people fell down, cried out and violently affected. 89

\section{Methodism, Societies, Mission}

A large proportion of Wesley's letters during his middle and later years were concerned with the development and well being of his societies. He needed to take care of a whole team of itinerant preachers and lay preachers. "By means of his letters, he guided his preachers' studies and their matrimonial ventures. He also sent them books and advanced them money. He advised them on their preaching, especially along the lines of a letter to Thomas Rankin, he said: "likewise be temperate in speaking - never too loud, never too long."90 His pastoral guidance did not limit to the lay people but also the leadership. It was precisely this kind of personal touch and care through guidance which eventually help his teams of preachers to more effectively spread the scriptural holiness. In fact, as the movement grows, much of the advancement of Methodism and the enforcement of the disciplines for both preachers and laities were done through his postal guidance. Large volume of letters was especially written to direct his preachers pertaining to such matters. His frequent correspondences with individuals such as Ebenezer Blackwell, Joseph Benson, James Bennett, Ann Bolton, Mary Bosanquet, Adam Clarke, John Fletcher, John Volton, Lady Huntington were also evidences of how he provide guidance in order that they may be his hand and feet to reach out and minister to more.

\section{Church, Ecumenical}

Wesley defined the Church of Christ as "a company of faithful people, of true believers", who have "the mind that was in Christ" and "walk as Christ walked". 91 In his letter to John Smith, he expounded his belief that ecclesiastical order is to bring souls from the power of Satan to God and to build them up in His fear and love. Orders which answer these ends are valuable. ${ }^{92}$ This again is none other than Wesley's commitment to guide all to the heart religion of the restoration of human imago dei and to attain perfection in the

\footnotetext{
89 John Wesley, The Letters, 7: 207 Jan. 21, 1784.

90 Frank Baker, "John Wesley, Postal Pastor", 45.

91 John Wesley, The Letters, 5: 245.

92 John Wesley, The Letters, 2: $77-78$.
} 
Christian living. Wesley held firmly to this theological conviction and it continued to motivate him to take that brave steps to preach in the open air, to take liberty to reform the church, to guide believers and even to go against the Church of England to ordain Thomas Coke for this commitment. In his lifelong correspondence with many others, there were many other ecclesiastical issues range from clergical to worship, rules and discipline. ${ }^{93}$

\section{others}

Wesley was never tired of helping members of the societies and classes to deal with their estranged relationship. The Jasper Winscom and his son's case was one among the many examples. ${ }^{94}$ Reconciliation and forgiveness in relationship is an outward sign of an inward renewal. Wesley continued to write to guide and promote such holiness of life.

Another prominent theme is Wesley providing his pastoral guidance for social issues in his letter writing. His letter to William Pitt, First Lord of the Treasury regarding issues such as smuggling, evasion of taxes and slavery showed clearly his conviction of social holiness. 95 Through his letter writing, he wanted to guide his coworkers to do the same. A good example is that of the termination of membership of some who smuggled in Newcastle society to leave the connexion and Wesley supported the move. ${ }^{96}$

These different themes from the letters demonstrated Wesley's commitment to the restoration of human imago Dei through proper guidance in almost all matters related to Christian day to day living. It makes sense for Wesley to see that every aspect of one's daily life is inseparable from the goal of a sanctified life. A sanctified life is a holistic life where every aspect is intact and moving toward the telos of loving God and neighbor.

\section{CONCLUSION}

Wesley sees Christianity particularly from the point of view of sanctification. Sanctification is regarded as an ethical transformation of heart and life of humanity to love God and neighbor. ${ }^{97}$ As discussed in this paper, Wesley strived in all this evangelical

${ }^{93}$ Cf. Appendix "Church" \& "Ecumenical”.

94 John Wesley, The Letters, 7: 192, 203.

${ }^{95}$ John Wesley, The Letters, 7: 234; 8:265.

96 John Wesley, The Letters, Oct. 22, 1778. 6:

${ }^{97}$ See his sermon "Scriptural Christianity", Albert C. Outler, The Bicentennial, I: 159 - 180. In "The Way to the Kingdom", Wesley summed up true religion as "righteousness" or "holiness" (which means loving God and 
pursuit to spread this "religion of love". He tirelessly and purposefully provided guidance for his people, the Methodists of the British Isles in the eighteenth century. True to this conviction, his sermons, letters and the instruction given to the life of the small groups (bands, societies, class meetings), either on the personal or communal level, Wesley continued to point them towards the goal of a sanctified life.

Wesley was also true to his scriptural conviction and was bold to take a more directive approach in guiding his people toward this telos. In his own theological framework, Wesley was convinced of the response-ability of each person to work of the Holy Spirit. He was further convinced of the possibility of the weakness along the path toward the goal of sanctification. He emphasized the means of grace and the many practical works of mercy and piety as the basic guidance to reach the goal. He was realistic and was ready to holding the tension of the grace of God in all these guidance with that of human response-ability and responsibility.

One of the wisdom and legacy of Wesley's pastoral guidance is perhaps his innovation in finding ways and means that were suitable and appropriate in his own context to guide his flock to a mature discipleship. His ingenious way of using particularly his written sermons to guide the Methodists to live a holy life not only benefited his generation but also ours. His letters reminded us of how he has overcome the kind of postal service of his time and the condition in which his letters written, we are convinced of his discipline, determination and most of all the conviction of providing pastoral guidance to the goal of loving God and neighbor. His instructions to the life in the small group provoked us to finding ways appropriate in our time and space to promote scriptural holiness in the lives of the twenty-first century Methodists. As Paul said: "We preach Christ, warning people not to add to the Message. We teach in a spirit of profound common sense so that we can bring each person to maturity."(Col. 1:28, emphasis mine). ${ }^{98}$

\section{REFERENCE}

Baker, Frank. “John Wesley, Postal Pastor”, James S. Udy \& Eric G. Clancy, Dig or Die: Papers

fellow creatures) and "happiness." (which comprises of peace, assurance of adoption, and joy in the Holy Spirit). I: $218-232$.

98 Eugene H. Peterson, The Message: New Testament with Psalms and Proverbs, (Colarado: Navpress, 1993), 500. 
given at Wesley Heritage Conference. Sydney 1980, Australia: World Methodist Historical Society, Australian Section, 1981.

Baker, Frank, Ed., The Works of John Wesley, (Letters: I), vol. 25, Oxford: Clarendon Press, 1980.

Collins, Kenneth. The Scripture Way of Salvation: The Heart of John Wesley's Theology. Nashville, TN: Abingdon Press, 1997.

Gill, Frederick C. Ed. Selected Letters of John Wesley. (New York: Philosophical Library, 1956.

Danker, Ryan N. "An Introduction," in Thomas Jackson, Ed. The Sermons of John Wesley 1872. Edition, http://wesley.nnu.edu/john_wesley/sermons/intro.html.

Green, V. V. H. John Wesley, London, Great Britain: Thomas Nelson, 1964.

Hardt, Philip F. The Soul of Methodism: The Class Meeting in Early New York City Methodism. Lanham, Maryland: University Press of America, 2000.

Harper, Steven. "John Wesley: Spiritual Guide" in Wesleyan Theological Journal, Vol. 20, No. 2 (Fall 1985): 91.

Holsclaw, David Francis. The Demise of Disciplined Christian Fellowship: The Methodist Class Meeting in Nineteenth-Century America, (Ann Arbor, MI: University Microfilm International, 1979)

Jackson, Thomas, Ed. The Works of John Wesley, Vol. 1 - 14 Address, Essays, Letters. Grand Rapids, Michigan: Zondervan Publishing House, 1872.

Jackson, Thomas, Ed. The Letters of The Rev. John Wesley, A.M. Vol. 1- 8. London: The Epworth Press, 1931.

John B. Cobb, Grace \& Responsibility: A Wesleyan Theology for Today, Nashville, TN: Abingdon, 1995.

Jonsson, Gunnllaugur A. The Image of God: Genesis 1:26-28 in a Century of Old Testament Research, Lund, Sweden: Almqvist \& Wiksell International, 1988.

Khoo, Ho Peng. “An Asian Reflection of John Wesley's Postal Ministry in The Light of His Understanding of New Creation", First Wesleyan Seminar, WFCMC. Taiwan, Taipei: World Federation of Chinese Methodist Churches, 2001.

Khoo, Ho Peng. "John Wesley and The Imago Dei”, Term Paper for John Wesley's Theology and The Imago Dei (21-951A), Spring 2004. 
Knight, Henry H. III. “Consider Wesley”, Joel B. Green, Ed., Catalyst: Contemporary Evangelical Perspectives For United Methodist Seminarians, vol. 30, No. 4, (April 2004): 7.

Linström, Harald. Wesley and Sanctification, Wilmore, Kentucky: Francis Asbury Publishing Co. Inc., 1980.

Outler, Albert C., Ed. The Works of John Wesley Vol. 1 - 4, Nashville, TN: Abingdon Press, 1985.

Outler, Albert C. \& Heitzenrater, Richard P. Ed. John Wesley's Sermon: An Anthology, Nashville, TN: Abingdon Press, 1991.

Randy L. Maddox. Responsible Grace: John Wesley's Practical Theology. Nashville, TN: Kingswood Book, 1994.

Rogal, Samuel J. “The Elder Unto The Well-Beloved”: The Letters of John Wesley, Journal of Religious Studies, Vol. 7, No. 2 (Fall 1979): 76.

Reist, Irwin W. “John Wesley's View of man: A Study In Free Grace Versus Free Will” Wesleyan Theological Journal Volume 7 No. 1, (Spring 1972): 27.

Runyon, Theodore. The New Creation: John Wesley's Theology Today, Nashville, TN: Abingdon, 1998.

Tracy, Wesley D. “John Wesley, Spiritual Director: Spiritual Guidance In Wesley’s Letters, Wesleyan Theological Journal Vol.23, No. 1 \& 2 (Spring Fall 1988): 148 - 162.

Watson, David L., Early Methodist Class Meeting: Its Origins and Significance. Nashville: Discipleship Resources, 1985.

Watson, David L., Class Leaders: Recovering a Tradition. Nashville, TN: Discipleship Resources, 1991.

Watzki, Steve. A Preliminary Defense of Prevenient Grace. http://www.imarc.cc/pregrace/v18n2witzki.html.

Wesley, John, Explanatory Notes Upon The New Testament. London: The Epworth Press, 1948. 